in support of the Government's foodfor-work programme launched in January, 1975. WFP's aid in Bangladesh is reaching only the very poorest sections of the community.

This aid is largely being used to reexcavate large stretches of canal and for the creation of embankments to contain floods with the object of assisting the production of an additional 200,000 tons of rice annually. During the first year (1975) some 200,000 workers turned out to work on this project in return for food rations, while in April, 1976, about 2 million were at work on some 1,500 sites. To date WFP has delivered 164,000 tons of wheat to this project and expects to deliver a further 65,000 in the course of 1977 .

By May, 1976, about 2,500 kilometers of canals and 3,000 kilometers of embankments had been completed, and it is estimated that workers had moved more earth than was excavated for digging the Panama Canal.

I feel sure you will concede that such work is carried out only by the poorest of the poor, who are thus, in return for food aid, revolutionizing agricultural possibilities in Bangladesh. We are satisfied from our field officers in Bangladesh and from evaluation missions that 100 per cent of the Programme's aid is going to the poorest sector and not to subsidize the Government's ration system for the middle classes.

Thomas C.M. Robinson
Executive Director ad interim
World Food Programme
Rome

Kai Bird and Sue Goldmark Respond:

- Mr. Thomas Robinson is quite correct to point out that not all food aid to Bangladesh benefits only the urban middle class. Food-for-work projects are sponsored by both the WFP and the U.S. Government through a CARE contract. Both programs have a good reputation among development experts in Dacca. Food-for-work projects do at tract the very poorest unemployed agricultural day laborers.

But as we stated in our recent article, only an average of 5 per cent of all food aid to Bangladesh is allocated to foodfor-work projects. And while we agree that current food-for-work projects can assist in stimulating domestic food production, there are limits to this type of assistance. Most observers agree that food-for-work projects cannot expand much beyond current levels without dislocating labor supplies needed for nnormal agricultural work.

At the high point of the WFP's foodfor-work project, in April, 1976, many recipients were taking their wheat payments and selling them on the open market in return for rice. This phenomenon contributed in part to the low disincentive price paid to local wheat farmers.

Another limitation on food-for-work projects is that most of the excavation of canals and drainage ditches must be completed during the dry seasonexactly the time of year when seasonally unemployed day laborers are most likely to find work. During the long monsoon season, when there is very little food or agricultural work available, food-for-work projects grind to a halt.

Food aid-such as the WFP's foodfor-work projects-can play a limited role in Bangladesh's development. But food for work is a secondary development tool and cannot substitute for the necessary reorientation of political and economic priorities away from the cities and into the countryside.

\section{The Conservative Menu}

To the Editors: I don't know who A. James McAdams is or where you found him, but it wasn't along Publishers' Row. He describes Arlington House as "unusual in that many of its books are not spontaneously submitted but are commissioned" (see his review of Thomas Molnar's Authority and Its Enemies in the March issue of Worldview). Editors at the other publishing houses will be disappointed to see their best efforts thus scanted. In point of fact, the most creative part of any editor's job is precisely the ability to dream up book ideas, then match them with appropriate authors. Arlington House does it-and so does every other publisher worthy of the name.

Mr. McAdams, noting that our sister company is the Conservative Book Club, remarks that Arlington House books go to a "captive audience," In certain moods, I wish it were so. But alas, the thirty or so books we publish annually must make their way in the marketplace in competition with the other forty thousand that America turns out every year. They do find a ready audience among members of the Conservative Book Club; but a captive audience? Well over half the members pass up even our most popular selections. And if we offer too many books a member doesn't like, he simply quits, just like his cousin in Book of the Month Club.

Does Arlington House "toe often" fail to get conservative authors at their best? We do have our lemon quota. It runs about the same as at Macmillan and Doubleday, where I worked before. Is qur "captive" audience "fed the same old arguments over and over again"? They do get ideas that express a broadly conservative position, even as readers of the New York Times enjoy their daily ration of liberalism. But if $\mathrm{Mr}$. McAdams will visit again und stay awhile, he will notice that the conservative menu is adding new dishes all the time.

Nowhere is Mr. McAdams less accurate (or generous) than when he labels Thomas Molnar a "hanger-on", of Arlington House. Dr. Molnar, a prodigious producer, is the author of over a dozen books in English alone. Apart from the book under review, Authority and Its Enemies, the only other time Dr. Molnar was lured by the Arlington House siren song was for a reprint of The Decline of the Intellectual. I hope the appearance of this book under the Arlington House imprint will not force Mr. McAdams to reconsider his tribute to it.

President

Neil McCaffrey Arlington House

New Rochelle, N.Y.

\section{A. James McAdams Responds:}

Mr. McCaffrey is right. I am not a book publisher. However, I am a book reader, and that fact alone should cause him some concern over my less than laudatory estimation of Arlington House.

It remains my impression that $\mathrm{AH}$ gets far fewer unsolicited manuscripts than other firms. From the many discussions I have had with conservative intellectuals, it has struck me that the best of these scholars tend to submit their independently written works (often their best works) to other houses. To the extent, however, that such scholars are 